\title{
Accepting the Grotesque Body: Bildungs by Clare Boylan and Eilis Ni Dhuibhne
}

\author{
by Jeanette Roberts Shumaker \\ San Diego State University, Imperial Valley
}

Copyright (c) 2006 by Jeanette Roberts Shumaker. This text may be archived and redistributed both in electronic form and in hard copy, provided that the author and journal are properly cited and no fee is charged for access.

\begin{abstract}
In Clare Boylan's fantasy novel Black Baby (1988) and Eilis Ni Dhuibhne's realistic novel The Dancers Dancing (1999), female protagonists fear those who symbolize the grotesqueness of their own overweight bodies; hence, these heroines reject marginalized women, either black or retarded, and Irish peasants. Through their heroines' struggles to accept both themselves and marginalized others, Ni Dhuibhne and Boylan deconstruct the psychology of self-hatred, whether it occurs in teenage or elderly women. Bakhtin's ideas about the grotesque body, along with Stallybrass and White's connection of the grotesque to prejudice, and Kristeva's theory of abjection illuminate the conflicts over self-acceptance that Boylan's and Ni Dhuibhne's heroines face.
\end{abstract}

Key Words: self-hatred, grotesque, women, body, abjection, overweight, fantasy, disability, African.

'Fair and foul are near of kin,

And fair needs foul,' I cried.

W. B. Yeats, "Crazy Jane Talks with the Bishop"

For the female protagonists of Boylan's Black Baby (1988), and Eilis Ni Dhuibhne's The Dancers Dancing (1999), maturation entails accepting the grotesqueness of their bodies. The female body erupts through excess weight and unruly sexual desires in both novels. For the teenage heroine of Dancers Dancing, selfacceptance means owning her resemblance to her retarded aunt, along with her own workingclass status. Whereas Ni Dhuibhne's heroine is young enough to broaden her approach to life, the elderly heroine of Black Baby is unable to rebuild hers, except in a comatose fantasy.

Distrust of women's bodies can be traced back to the early Christian Church in Ireland. A preoccupation with protecting the chastity of monks led to carvings depicting women as seductresses, and to gender-specific convents, churches, and even burial grounds during the Dark and Middle Ages (Wood 1985: 19-20). In the fifteenth and sixteenth centuries, grotesque carvings of female figures displaying their genitalia were placed on castles and churches. These Sheela-na-gigs were intended to protect buildings from destructive forces (Wood 1985: 22). Such traditional fears of feminine monstrosity play a role in Boylan and $\mathrm{Ni}$ Dhuibhne's novels.

Lack of self-esteem in women supports inequities of the gender structure, according to Peter Stallybrass and Allon White. Women and others who are put at the bottom of the gender or class structure accept their position as deserved due to their lowly qualities. Stallybrass and White argue that projecting the grotesqueness of one's body onto those seen as other is a strategy that the middle class historically has used to achieve supremacy and high self-esteem: "The bourgeois subject continuously defined and redefined itself through the exclusion of what it marked out as 'low' -as dirty, repulsive, noisy, contaminating" (1986: 191). Sublimation of "low" desires has been the middle class's way of exercising cultural domination (Stallybrass 1986: 197). 
Boylan's and Ni Dhuibhne's heroines solidify their identification with middle-class fears through rejecting those who represent their own grotesqueness -marginalized women, either black or retarded, and Irish peasants. These protagonists also try to sublimate their desires to fit middle-class expectations. However, the protagonists fail to enhance their self-esteem and status through these ploys. Instead, they feel guilty and cheated, as they deny themselves the sensual and social pleasures that they associate with marginal people. Through their heroines' struggles to accept themselves and marginalized others, Ni Dhuibhne and Boylan deconstruct the psychology of feminine selfhatred.

Mikhail Bakhtin's ideas about the grotesque body, along with Stallybrass and White's connection of the grotesque to prejudice, illuminate the conflicts over self-acceptance that these Irish protagonists face. According to Bakhtin, the grotesque "frees human consciousness, thoughts, and imagination for new potentialities" (1968: 49). Bakhtin argues that "The essence of the grotesque is precisely to represent a contradictory and double-faced fullness of life. Negation and destruction (death of the old) are included as an essential phase, inseparable from affirmation of the birth of something new and better" (1968: 62). Once one faces the decaying underside of life, one is free to live a richer, less judgmental and resentful existence.

That Boylan's plot depends upon a trick is itself carnivalesque. The reader does not realize that elderly Alice is in a coma during the second half of the novel. Instead, it appears that Alice's life is taking improbable, entertaining turns punctuated by witticisms. Not until the end of the novel is it clear that its last hundred pages describe a fantasy Alice invents during her coma. Boylan has created a novel of tricks that Jean-Louis Giovannangeli associates with Bakhtin's portrayal of medieval carnivals (1996: 178). Bakhtin describes carnivals that include "popular tricks" befitting "a world of topsy-turvy, of heteroglot exuberance" (Stallybrass 1986: 8). Boylan's references to the Bakhtinian carnival suit her story of an old woman's liberation from repressive rules of class, race, and gender.

Boylan also alludes to the Gaelic literary genre of the vision in allowing Alice's comatose dreams to free her. Like Alice in
Wonderland, Boylan's Alice manages to avoid the madness stereotypically associated with the Celts. Rather than madness, Alice's vision is analogous to exile. As Gerry Smyth writes, "Exile can be an interior process of alienation from the narrow definitions of homeland which characterize post-revolutionary Irishness" (1997: 43). When Alice has a vision of opening her home to a homeless black woman, she escapes the xenophic paranoia of her parents.

Black Baby is filled with disturbing, grotesque humor that complements its theme of freedom from prejudice. In his pioneering study of Irish comedy, Vivian Mercier argues that grotesque humor is "a defense mechanism against the fear of sex" (1962: 49). Alice is an ancient virgin who finally overcomes her Puritanical fear of sex through earthy fantasies; for example, Alice dreams that a prostitute's baby turns into a pig in Alice's arms. Boylan uses such carnivalesque humor to criticize Irish prudishness.

Some of the roots of Irish racism lie in the nation's missionary tradition: "Ireland's missionary tradition has meant that Irish people have played their part in reinforcing and continuing the effects of colonialism" (Fitzgerald 1994: 254). They "created an elitist and divisive structure within communities visited by missionary groups" (Fitzgerald 1994: 254). Boylan depicts the damage created by Irish missionaries through Dinah's trauma as the child of an immigrant African mother. Dinah's mother became an alcoholic in reaction to the disruption of her culture by Irish missionaries; she tells Dinah stories of idealized Irish missionaries who inspired her to hate herself for being black, along with inspring her to emigrate to a Western nation where she would be distrusted. In this novel Boylan also comments upon the generations of Irish children, including Alice, who were convinced by the Church to donate money to the missions. To move their generosity, children were told they were not only sponsoring, but buying dark-skinned, foreign babies. As a black, Irish theorist, Geraldine Fitzgerald regards this as a horrifying practice (1994: 255). Boylan's tragicomic plot makes readers question the practice of buying black babies, and see the racism that underpins it.

Black Baby is timely because racism has been increasing throughout Europe since the 1980s (Fitzgerald 1994: 264). During the 
1990s, refugees from Eastern Europe moved to Ireland; Irish people sometimes speak resentfully of the burden refugees place upon the welfare system, and accuse them of various scams. Though Boylan only deals with racism against blacks, that Ireland is experiencing increasing immigration rates makes Black Baby especially meaningful. Nevertheless, the traditional object of racism in Ireland is Travelers of supposed Gypsy extraction; indeed, blacks like Dinah are a tiny fraction of the population (Fitzgerald 1994: 257).

Alice's fantasies during her coma lead her into the world of Bakhtin's carnival. This is a world that the middle class, to which Freud's patients belong, rejects: "Freud's patients can be seen as enacting desperate ritual fragments salvaged from a festive tradition, the selfexclusion from which had been one of the identifying features of their social class" (Stallybrass 1986: 176). Alice's fantasy during her coma is composed of such fragments of primitive experiences that her Puritanical mother denied her. For example, Alice imagines that Dinah cooks sausages over an outdoor fire in their garden as part of a holiday celebration. Alice is having a carnivalesque fantasy, manifested partially by the odor and taste of meat fat, noted by Stallybrass and White as the main symbol of Mardi Gras (1986: 184). Discussing Bakhtin's carnival, Dustin Griffin observes that "Apparent death and destruction instead lead to the sustenance of life through the offering of food" (1994: 196). Alice's coma, then, is not merely a sign of approaching death, but a mental feast. Although Alice never really gets the opportunity to experience the pleasure of eating meat that is dripping with fat during ritual festivities, her mind fools her (and us) into thinking she is having that joy. Her body is trapped by immobility, but Alice's unconscious is free. It dominates her comatose existence, compensating for decades of bondage to her overly developed superego. By making Alice's fantasy plausible, Boylan depicts the supremacy of imaginary experience compared to actual life. In Alice's case, that primacy is merciful, since her mind is all she has after her stroke.

Alice's coma is a liminal state. Judy Little's study of feminist comedy notes that liminality is often employed by women. "The paradigm of the hero's quest . . . incorporates these liminal motifs of death, a journey through wilderness or darkness, and often a journey into landscapes vaguely feminine or maternal in imagery" (1983: 4). Alice goes on such a quest during her coma. The home Alice invents can be seen as the feminine landscape of which Little speaks, redecorated by Dinah to provide coziness and beauty at last. As part of her transformation into a nurturing mother, Alice learns to tolerate Dinah's sexual relationships with men, and tells her that she will have "every advantage" (Boylan 1988: 126). Alice has learned from Dinah that "We cannot stoop to love one another in case we might muddy our souls. We live in this dirty world. We're put here by God, who made it" (Boylan 1988: 123). Dinah's version of Crazy Jane's lesson transforms Alice into a model fantasy parent.

In reality, Alice's mother was the opposite sort of parent. Since Alice's childhood, her mother forced Alice to overeat, presumably to make her too heavy to attract men. Alice's selfesteem suffered as a result. Her mother never explained menstruation, so Alice regarded it as a punishment for her vain, sinful aspirations to be thin. Consistent with forcing Alice to become unattractive, her mother denied Alice two suitors: a black doctor whom Alice loved but never dared to introduce to her parents; and a white, middle-aged man to whom she became attached years later. Had Alice dared to marry the doctor, she might have had a mixed race daughter like Dinah in reality. Alice's mother rejected the second suitor, Mr. Gosling, on the basis of class rather than race. In the nineteenth century, "the poor were interpreted as also transgressing the boundaries of the 'civilized' body and the borders which separated the human from the animal" (Stallybrass 1986: 132). Still believing such ideas in initial decades of the twentieth century, Alice's mother frightens her daughter with tales of Mr. Gosling's animalistic lust.

Like Alice's mother, Dinah's denies her daughter's need for romantic love, forcing Dinah to have an abortion as a teenager. Both Alice's and Dinah's mothers strangle their daughters' development because they want to secure their services permanently. Would Alice copy her mother's example and mistreat Dinah, her adopted daughter? Is that why Alice offers Dinah a servant's bedroom? Perhaps Dinah is aware of the danger in her attraction to Alice, though Dinah does not state it; another motherchild bond could drain what youth is left to her. Nevertheless, Dinah, like Alice, nurtures 
fantasies that enthrone Alice as her mother, though she reveals her ambivalence towards the old lady when she tells Figgis of Alice's racism and snobbery.

Alice and Dinah are alike in having sacrificed themselves as daughters: due to a lack of other experiences, they may only feel comfortable centering their lives upon a vexing mother-daughter bond. Alice's comatose fantasy allows her to reinvent the motherdaughter relationship, minimizing daughterly sacrifice and increasing motherly affection. Annis Pratt et al. observe that in women's literature, "the quest of the mother for the daughter leads to the rebirth of the mother" (1981: 172). That is the case for Alice.

Alice's happy maternal dreams are renegade in that they transcend the real, problematic relationships that she has known. "Comedy which implies, or perhaps even advocates, a permanently inverted world, a radical reordering of social structures, a real rather than temporary or merely playful redefinition of sexual identity, a relentless mocking of truths otherwise taken to be self-evident or even sacred -such comedy can well be called subversive, revolutionary, or renegade" (Little 1983: 2). This is true of Black Baby, with its reversal of the disappointing real world during Alice's coma. The inverted world is an utopia of love, tolerance, and sensual freedom compared to the real one. As another critic of women's comedy writes, "The world turned upside down can prove that the world has no rightful position at all" (Barreca 1994: 33). Boylan suggests this through her touching fantasy that makes the reader wish Alice had changed her life before her stroke. The novel's message is that it is not easy to change one's prejudices. The real Alice and Dinah are confined by the powerful ideologies of race, gender, and class that Alice's dreams contradict.

Victimized by these ideologies to a greater extent than Alice, Dinah, because of her skin color, is seen as a symbol of the grotesque body by all who meet her. Her mother had regarded Dinah as a servant or apprentice Mammy. Alice, in her coma, turns this view around, viewing Dinah as her savior from traditional limitations. If Alice symbolizes Ireland, as Teresa O'Connor suggests, Dinah awakens the Irish imagination beyond the complacency of homogeneity (1996: 7). Though Alice projects all kinds of low traits onto Dinah, Alice, in her coma, regards Dinah as an alchemist who turns such traits into golden ones. Dinah tells Alice, "Maybe I am some kind of gravedigger. Maybe I was sent here to dig up your past" (Boylan 1988: 114). To Alice, Dinah is both therapist and confessor. Not only Alice, but other whites stereotype Dinah. In Alice's comatose dreams, Dinah serves many Dubliners as an oracle of self-acceptance and joy; the people who eat at Dinah's cafe see her in a religious light as a bawdy prophet of self-realization.

Even Dinah regards herself as a projection of Irish expectations of African identity. Hence, she conceals her hometown of Brixton from Figgis and Alice, and takes on the new name of Dinah that Alice gives her. Dinah's identity as an exotic attracts Alice and Figgis; Dinah senses that the truth might repel them. Not surprisingly, when Dinah does tell Figgis her real name (Cora) and hometown, he does not believe her. At the novel's end, a second old white lady mistakes Dinah for her lost daughter. This suggests the larger issue Dinah faces of having whites appropriate her as a projection of their own needs. Under the unfair pressure of having to be what others want her to be, she mistakenly calls herself "a fraud" (Boylan 1988: 160). Dinah's self-alienation and her fantasies of escape are the results of the stereotypes that the Irish -represented by Alice, Figgis, and the second old lady- project upon her. Like Dinah's real mother, Alice does not recognize Dinah for the person she is, seeing Dinah rather as the fulfillment of maternal desires. Alice's mental exploitation of Dinah depersonalizes the young woman, however unintentionally, as carnivalesque thinking can. A carnival, as Bhahktin sees it, often "demonizes" marginal groups such as "women, ethnic and religious minorities" (Stallybrass 1986: 19). Dinah is not exactly demonized, but Alice and Figgis objectify Dinah as an African redeemer of the grotesque body.

Dinah wonders what she knows of Africa, outside of her mother's stories. Caught between European and African cultures for which she is likewise an outcast, Dinah not only lacks a mother, but also a motherland that might value her. She could easily turn into a black version of Alice someday, disaffected and alone; Dinah would be even more of an outcast than Alice, lacking the privileges of affluence and whiteness that shelter Alice. There is no fairy- 
tale solution for Dinah, not even the coma that eases dying Alice. Boylan ends her novel with a challenge to the real Ireland to secure a worthy place for Dinah, where a black woman would no longer be a sign of the maligned yet desired body.

Romantic and modernist authors often "stage a festival of the political unconscious and reveal the repressiveness and social rejections which formed it" (Stallybrass 1986: 200). Boylan does the same thing in her postmodern fantasy. She exposes Alice's repression as life-robbing, compared with her animating fantasies during her coma. More disturbingly, Boylan shows that Dinah must endure a reality in which "social rejections" poison the lives of the minorities and women who are unfairly linked to the lowly body.

Like Boylan's Alice, Eilis Ni Dhuibhne's Orla feels ambivalent about a marginalized woman whom she sees as a mirror of her own grotesqueness. In The Dancers Dancing, Orla's Auntie Annie is disabled, not black like Dinah. That Alice imagines a blood relationship with Dinah expresses the intensity of her need for a daughter to cure her self-loathing; conversely, Orla, who has plenty of living relatives, disowns her aunt. Although Orla has known Aunt Annie all her life, Alice knew Dinah only a few months before the old lady died. Whereas Dinah is much younger than Alice, Annie is much older than Orla.

Though Orla is young and Alice is elderly, they have much in common, for they both grow through accepting the woman who reflects their deepest fears about themselves. But their growth is not linear. Looking at the patterns of protagonists' development in women's literature throughout the world, Pratt et al. comment: "My material depicts a circle rather than an evolution, the older and transformed women heroes having far more in common with the uninitiated young women than with the characters most integrated within the social enclosure" (1981: 169). Alice grows back into her unprejudiced, youthful self, whereas Orla grows out of priggish, premature rigidity. Both Alice and Orla initially regard the women who will become so crucial to their own self-acceptance -Dinah and Annie- as representing alien, exotic worlds -Africa and western Ireland.

Located in the northwest of the Republic and bordering Northern Ireland, County Donegal is the site of Irish language colleges to which urban children are sent each summer to learn Gaelic, and, somewhat unrealistically, become truly Irish as a result. Since the late 1800 s, the west of Ireland has been idealized as the seat of "national vitality . . . language, manners, and dress" (Connolly 2003: 8). Though Orla wants to be patriotic, she is afraid to acknowledge her Donegal aunt, for she links the Dublin teenager to what she regards as peasant backwardness.

The mixture of attraction and repulsion towards another woman that Orla and Alice feel can be understood through applying the psychoanalytic theory of abjection. Julia Kristeva defines the abject as "the not-I"; its recognition engenders loathing for certain foods, corpses, and even classes of people whom one associates with death (1982: 2). Through her theory of abjection, Kristeva explains the age-old hatred of marginalized groups such as blacks, women, the disabled, and Jews. Abjection occurs when we avoid our fear of death by projecting the traits that we associate with decline onto ostracized others. What we label abject varies depending on our prejudices, but the process of abjection is intense, universal, and ancient. Kristeva writes: "There looms, within abjection, one of those violent, dark revolts of being, directed against a threat that seems to emanate from an exorbitant outside or inside, ejected beyond the scope of the possible, the tolerable, the thinkable" (1982: 1). Since decay can manifest itself internally, human fluids, exotic foods, and sexual acts may be seen as abject, as can symbols of moral corruption such as sin. But because decline may come from "outside" as well as "inside," marginalized groups are viewed as sources of contagion as well as manifestations of one's own secret decay.

Which qualities in others raise the specter of our own decay? Kristeva observes that "the in-between, the ambiguous, the composite" tend to stimulate repulsion because it disturbs our sense of identity and order (1982: 4). Auntie Annie's imperfect appearance, deafness, and lack of coordination cause such a reaction in Orla: "There is plenty wrong with her [Annie] that Orla can see: she is out of kilter, not plumb with the world. Her face is crooked, her mouth is crooked, and she walks with a clumsy and awkward gait" (Ni Dhuibhne 1999: 138). Annie talks in "a jerking staccato, screeching one minute, inaudible the next" (Ni Dhuibhne 1999: 139). Orla's 
revulsion towards her aunt increases each time a Donegal native tells her that she looks like Annie. With these words, Orla's worst fear comes true -that her excess weight makes her share the ugliness of her aunt. Orla's fear increases because of her pride in her intelligence: she plans to escape the working class by becoming a teacher or civil servant. To Orla's chagrin, Annie is not only disabled physically, but mentally as well: "her closest relation in it [Tubber] is the valley simpleton" (Ni Dhuibhne 1999: 140). Annie's mental and physical defects thus challenge Orla's identity, present and future.

Orla's shame about her lowly class status augments her paranoia about having her friends find out that she is Annie's niece. Unlike her middle-class friends, Orla lives in a Dublin lodging house, where she shares a bedroom with her parents. A related source of shame for upwardly mobile Orla is her father's position of bricklayer. Elizabeth and Orla conceal his manual labor through euphemisms that make him sound like the manager of a building site. Nonetheless, his physical work pays for their new clothes. As with the family's lodging house, Orla is ambivalent about her father's job that supports her.

A further source of shame concerns her family's use of English. Although Orla aspires to speak English perfectly like the Bobbsey twins, who constitute her ideal, her parents speak ungrammatically, proving their workingclass origins. That Orla aspires to be like the Bobbsey twins of her favorite novels suggests that she sees the Irish as inferior to the English. It also suggests that Orla sees the wealthy as superior to their employees, manual laborers like her father. Because of the prejudices of nation and class that Orla holds due to her reading, Orla does not agree with Elizabeth that Donegal is the best part of Ireland. As Joyce's Gabriel in "The Dead" would prefer to visit Europe rather than western Ireland, Orla would prefer to visit Cornwall like the Bobbsey twins. "Orla represents the postcolonial Irish who are ashamed of their Irishness," commented Ni Dhuibhne in an interview (Moloney 2003: 104).

Unlike her daughter, Elizabeth is not Irish, but English. She grew up in an English resort town where she peddled food to tourists. Perhaps Elizabeth idealizes Donegal because to her it is exotic -a place where she has never worked, but enjoyed respect as a married visitor from the city. Orla is surprised when Elizabeth, talking to her Dublin friends, mistakenly portrays Annie's house as their family's summer cottage. On the other hand, Orla's ideal, the Bobbsey twins, might for Elizabeth be associated with the oppressive British upper class. The only letter that Elizabeth sends Orla while she attends Irish college lacks punctuation and is full of spelling errors, reminding the girl that her mother is uneducated. Orla envies Aisling: her friend has educated, middle-class parents, a name-brand wardrobe, an allowance, and a pretty, private bedroom. In addition to working-class status and a peasant heritage, Orla's most painful source of shame is her appearance. She and Elizabeth buy clothes on sale that are never as fashionable as Aisling's. Orla also feels ashamed that she is heavy, unlike the models who adorn women's magazines. Given Orla's insecurities about her appearance and class status, Annie's deficiencies stimulate an abjective reaction that is a projection of Orla's self-loathing. Orla's abjective reaction to her aunt makes her behave with cruel neglect; even when Annie's life appears to be at risk, Orla won't run for help because that would entail admitting she is her niece.

Attractive young Michael's acceptance of Annie is the key to improving Orla's view of her aunt. His approval of Annie is typical of the people of Tubber, who "love the poor and the failures" (Ni Dhuibhne 1999: 141). They help their neighbors unstintingly, since their relatives live all over the world, too far away to be depended upon. In Michael's eyes, being related to Annie makes Orla a Tubber girl, not an inaccessible outsider like the other students from the Irish college. If Orla had not shared the surname Crilly with Annie, Michael would never have spoken to her.

Orla does not realize that another student at the Irish college feels self-loathing as a result of similarly divided loyalties. Coming from Derry, Pauline suffers because her father is Protestant and her mother is Catholic. "And it is Pauline alone who dances the dangerous dance across the minefield that divides her mother's and her father's territory" (Ni Dhuibhne 1999: 103). Like Orla, Pauline feels confused about her identity because it has contradictory components. Whereas Orla must reconcile the polarities of country and city, Pauline must reconcile hostile divisions between Catholic and Protestant. 
Although they do not recognize it, Orla's and Pauline's common ground of vexing allegiances is the novel's central concern. "In the magical west the girls from Dublin meet their more worldly Northern Irish counterparts, who carry the knowledge of violence and injustice with them in the present"; it is 1972, the year after internment of political suspects without trial was introduced in Northern Ireland (Connolly 2003: 12). Ni Dhuibhne's reference to Pauline dancing in a "minefield" suggests the point of her novel's title. Identity must be negotiated delicately, with skill, given the complexities of religion, class, nation, and gender with which these teenagers must cope. Whereas Orla takes refuge from these complexities by hating her aunt, Pauline escapes by engaging in risky actions such as skinny-dipping with a boy in the middle of the night during a rainstorm. Both girls try to dance themselves into a solution to their unrest with themselves.

The last chapter of the novel is the only one narrated in first person. This implies the possibility that the novel is a dramatized memoir of either Orla or of the author herself. The novel ends with the persistence of Orla's memory of Michael long after Orla has become a wife and mother; Orla still contains the teenager learning to appreciate the beauty of her aunt's Ireland through falling for a boy who caught a salmon with his bare hands.

Like Michael, the forbidden burn is another symbol of the exotic allure of Donegal. For Orla, the burn is associated with the abject status of her body, class, and nation. Paradoxically, at the burn, Orla feels joyously free. She enjoys its coolness and beauty, and forgets to fear falling into its deep pool. At the burn, Orla finds a secret hoard of infant skulls -a dozen of them. The burn is not a killeen, an unblessed graveyard where unbaptized infants who died of natural causes are buried. Orla tells no one of her discovery, but it causes her to have nightmares. Through this incident, the peasants of Orla's ancestry are associated with murder as well as with the Celtic twilight quaintness purveyed by the Irish college Orla attends.

Until recently, there was a much higher rate of permanent singleness in Donegal than in the rest of Ireland (Shanklin 1985: 85). In the west of Ireland after the Famine, late marriages and high rates of singleness became common as a way to avoid causing another famine (Shanklin
1985: 84, 104). Perhaps an inability to afford marriage, combined with Puritanical strictures against so-called loose women, resulted in the murder of the infants buried at the burn.

The novel's epigraph, from Gerard Manley Hopkins's poem about a burn, "Inversnaid," suggests that one of $\mathrm{Ni}$ Dhuibhne's central themes is apprehending the beauty of nature, despite its irregularities. The novel's opening meditation also suggests this, as it offers a distant view of Donegal that one would see from an airplane or when drawing a map. The opening then moves to a close-up of the burn, with its story described as being "Clear as muddy old mud" (Ni Dhuibhne 1999: 3). At the burn, Orla learns to love the messiness of nature; she builds upon this love to accept natural passions in herself, as well as the appealing ungainliness of Annie and the untutored grace of Michael.

Alice's dreamed encounter with nature occurs in her father's garden, not in a wild place as Orla's real encounter does. Surrounded by green abundance, Boylan's Alice, like Orla, learns to own her body, including its sexuality. Within an environment of growing plants, obsessions with class status or ethnic hierarchies appear petty. Tolerance of death supplants abjective reactions to the signs of the decay that humans must confront. Orla faces her own mortality, mirrored in the imperfections of her Aunt Annie. Eschewing the racism and classism of her parents that made her treat Dinah ambivalently, Boylan's Alice at last comes to terms with her own imminent death. What is sad about Alice's fate is not that she dies, but that she has never really lived. The life Alice leads in her comatose dreams is the one she might have enjoyed, if she had had the courage. Orla avoids Alice's doom of having endured a static death-in-life reminiscent of the paralysis of characters in Dubliners; instead, Orla learns to value her body, class, gender, and nation while she is still young enough to enjoy life's pleasures. With their focus upon obstacles to self-acceptance, Boylan's and Ni Dhuibhne's novels of female development deviate from the traditional marriage plot. Instead, Boylan and Ni Dhuibhne create an alternative plot of women, old and young, learning to appreciate themselves and other marginalized groups.

In a study that compares twentieth-century novels by Irish women and men (not including those described in my essay), James W. 
Cahalan argues that bildungsromane by men tend to privilege individualism, whereas those written by women tend to privilege communalism (1999: 108). His view confirms that of Elizabeth Abel, Marianne Hirsch, and Elizabeth Langland in their collection of essays about the female bildung in European and American literature during the nineteenth and twentieth centuries: "Historically, only the masculine experience of separation and autonomy has been awarded the stamp of maturity; feminist theory suggests that the insistence on relationship reveals not a failed adulthood, but the desire for a different one" (Abel 1983: 10). In her comatose dreams, Boylan's Alice struggles to take such a feminine path of connection across races, classes, and generations. Ni Dhuibhne's Orla starts on such a path as she accepts the grotesqueness of her aunt that reminds her of her own. By the end of each novel, the heroines created by Ni Dhuibne and Boylan learn to conform to the feminine path of communal values that Cahalan and Abel et al. describe.

Abel et al. also report that bildungsromane about women tend to follow either a pattern of apprenticeship or one of awakening (1983: 11). Orla's development follows a line of apprenticeship, whereas Alice paradoxically experiences a spiritual awakening during the profound sleep of her coma. Such Gothic twists are commonly submerged in bildungsromane by British women writers, too, suggesting that horror typically plays a role in women's development (Fraiman 1993: 10).

Whether involving plots of apprenticeship or awakening, female bildungsromane often include a surface plot that "affirms social conventions, and a submerged plot, which encodes rebellion" (Abel 1983: 12). Boylan's submerged plot is the fantasy that Alice imagines during her coma, in which class, gender, and racial hierarchies are inverted to place a working-class, black woman at the top. The submerged plot in Ni Dhuibhne's novel involves Orla's decreasing shame about her body, her aunt, and her social class. These submerged plots involve the conflict between the individual and social convention that characterizes the original bildungsroman for men which developed in Germany during the eighteenth century (Abel 1983: 6).

In bildungsromane by women, "an exfoliation of narratives is typical, suggesting a veritable wilderness of confidences and anxieties about becoming female" (Fraiman 1993: 144). This is true of Black Baby and The Dancers Dancing. Boylan shows the possibilities for Dinah's development as well as Alice's, and includes subtly intertwined realistic and fantastic narratives that incorporate both comedy and tragedy. Dancers traces the development of Pauline as well as Orla. Like Boylan's use of foils, Ni Dhuibhne's doubling of protagonists encourages the reader to compare and contrast the two. Again resembling Black Baby, Dancers incorporates a variety of narrative tones and moods. $\mathrm{Ni}$ Dhuibhne employs vignettes, rather than juxtaposing realistic and fantastic narratives as Boylan does.

As the protagonists of these novels struggle to accept themselves, they also struggle to separate themselves from disparagement of the female body. Dinah comes closest to eluding such disparagement. Through questioning the grotesqueness of the female body and the socalled lowliness that it signifies, Boylan and $\mathrm{Ni}$ Dhuibhne become part of "the countertradition of the Irish novel which can be understood as an attempt to escape the limitations of the nation's colonial heritage and the manner in which it was forced to construe the world in terms of rigidly defined, oppositional categories -Irish and English, woman and man, national and alien" (Smyth 1997: 43).

\section{Works Cited}

Abel, Elizabeth, Marianne Hirsch, and Elizabeth Langland. 1983. The Voyage In: Fictions of Female Development. Hanover: UP of New England.

Bakhtin, Mikhail. 1968. Rabelais and His World. Trans. Helene Iswolsky. Cambridge: Massachusetts Institute of Technology P.

Barreca, Regina. 1994.'Untamed and Unabashed': Essays on Women and Humor in British Literature. Detroit: Wayne State UP.

Boylan, Clare. 1988. Black Baby. 1988. London: Little Brown.

Cahalan, James W. 1999. Double Visions: Women and Men in Modern and Contemporary Irish Fiction. Syracuse: Syracuse UP.

Connolly, Claire. 2003. Theorizing Ireland. New York: Palgrave.

Fitzgerald, Gretchen. 1994. "Repulsing Racism: Reflections on Racism and the Irish". A Dozen LIPS. Dublin: Attic. 249-68. 
Fraiman, Susan. 1993. Unbecoming Women: British Women Writers and the Novel of Development. New York: Columbia UP.

Giovannangeli, Jean-Louis. 1996. "Joyce and Boylan's Black Baby: 'Swiftly and Silently'". Ed. Teresa O'Connor. The Comic Tradition In Irish Women Writers. Gainesville: UP of Florida. 171-82.

Griffin, Dustin. 1994. Satire. Lexington: UP of Kentucky.

Kristeva, Julia. 1982. Powers of Horror: An Essay on Abjection. Trans. Leon S. Roudiez. New York: Columbia UP.

Little, Judy. 1983. Comedy and the Woman Writer. Lincoln: U Nebraska P.

Mercier, Vivian. 1962. The Irish Comic Tradition. Oxford: Clarendon.

Moloney. Caitiona and Helen Thompson. 2003. Irish Women Writers Speak Out: Voices from the Field. Syracuse: Syracuse UP.
Ni Dhuibhne, Eilis. 1999. The Dancers Dancing. Belfast: Blackstaff.

O'Connor, Teresa, ed. 1996. "Introduction". The Comic Tradition in Irish Women Writers. Gainesville: UP of Florida.

Pratt, Annis, Barbara White, Andrea Loewenstein, and Mary Wyer. 1981. Archetypal Patterns in Women's Fiction. Bloomington: Indiana UP.

Shanklin, Eugenia. 1985. Donegal's Changing Traditions. New York: Gordon and Breach.

Smyth, Gerry. 1997. The Novel and the Nation: Studies in the New Irish Fiction. London: Pluto.

Stallybrass, Peter and Allon White. 1986. The Politics and Poetics of Transgression. Ithaca NY: Cornell UP.

Wood. Helen Lanigan. 1985. "Women in Myths and Early Depictions." Eilean Ni Chuilleanain, ed. Irish Women: Image and Achievement. Dublin: Arlen House. 13-24. 